\title{
Saccharification of ozonated sugarcane bagasse using enzymes from Myceliophthora thermophila JCP 1-4 for sugars release and ethanol production
}

\author{
Josiani de Cassia Pereira ${ }^{a}$, Rodolfo Travaini ${ }^{\mathrm{b}}$, Natalia Paganini Marques ${ }^{\mathrm{c}}$, Silvia Bolado-Rodríguez ${ }^{\mathrm{b}}$, \\ Daniela Alonso Bocchini Martins ${ }^{\mathrm{c}, *}$ \\ a Department of Biology, IBILCE/UNESP - Univ Estadual Paulista, Rua Cristóvão Colombo, 2265, 15054-000 São José do Rio Preto, São Paulo State, Brazil \\ ${ }^{\mathrm{b}}$ Department of Chemical Engineering and Environmental Technology, University of Valladolid - UVa, Calle Doctor Mergelina, s/n, 47005 Valladolid, Spain \\ ${ }^{c}$ Department of Biochemistry and Chemical Technology, IQ/UNESP - Univ Estadual Paulista, Rua Prof. Francisco Degni, 55, 14800-060 Araraquara, São Paulo State, Brazil
}

\section{H I G H L I G H T S}

- Myceliophthora thermophila JCP 1-4 is a new enzymes source for biomass hydrolysis.

- A fast $8 \mathrm{~h}$ hydrolysis was enough for ozonated sugarcane bagasse saccharification.

- The fungus was highlighted as a glucose isomerase producer, releasing fructose.

- Ozonated sugarcane bagasse acted as enzymes activities activator during hydrolysis.

- Hydrolysate from ozonated bagasse was greatly fermented for bioethanol production.

\section{A R T I C L E I N F O}

\section{Article history:}

Received 13 October 2015

Received in revised form 16 December 2015

Accepted 17 December 2015

Available online 23 December 2015

\section{Keywords:}

Sugarcane bagasse

Enzymatic saccharification

Ozonolysis

Fungal enzymes

Ethanol

\begin{abstract}
A B S T R A C T
The saccharification of ozonated sugarcane bagasse (SCB) by enzymes from Myceliophthora thermophila JCP 1-4 was studied. Fungal enzymes provided slightly higher sugar release than commercial enzymes, working at $50{ }^{\circ} \mathrm{C}$. Sugar release increased with temperature increase. Kinetic studies showed remarkable glucose release $\left(4.99 \mathrm{~g} / \mathrm{L}, 3 \% \mathrm{w} / \mathrm{w}\right.$ dry matter) at $60^{\circ} \mathrm{C}, 8 \mathrm{~h}$ of hydrolysis, using an enzyme load of $10 \mathrm{FPU}$ (filter paper unit). FPase and $\beta$-glucosidase activities increased during saccharification $(284 \%$ and $270 \%$, respectively). No further significant improvement on glucose release was observed increasing the enzyme load above 7.5 FPU per g of cellulose. Higher dry matter contents increased sugars release, but not yields. The fermentation of hydrolysates by Saccharomyces cerevisiae provided glucose-to-ethanol conversions around to $63 \%$.
\end{abstract}

(c) 2015 Elsevier Ltd. All rights reserved.

\section{Introduction}

The use of lignocellulosic residues - such as SCB - as raw material for second generation fuels production is a promissory research field. Lignocellulosic wastes stand out as a renewable bioenergy resource to reduce environmental, economic and political problems related to the use of the traditional fossil fuels. These residues can be used as substrates for microbial enzymes depolymerization

Abbreviations: AIL, acid insoluble lignin; ASL, acid soluble lignin; CBU, cellobiohydrolase unit; FPU, filter paper unit; SCB, sugarcane bagasse; HPLC, high pressure liquid chromatography; SSF, solid state fermentation; TL, total lignin.

* Corresponding author. Tel.: +55 1633019671; fax: +55 1633222308.

E-mail addresses: josianipereira@gmail.com (J. de Cassia Pereira), rtravaini@gmail.com (R. Travaini), nmarques@iq.unesp.br (N. Paganini Marques), silvia@iq.uva. es (S. Bolado-Rodríguez), dbocchini35@gmail.com (D.A. Bocchini Martins). to produce monomeric sugars that can be converted into second generation and other biobased products.

Brazilian government established, in 1975, the PRO-ÁLCOOL program, a policy to reduce the dependence from another countries fuel. The program was based in the increase of SCB ethanol production to be used as gasoline substitute as well as to blend it in a proportion up to $24 \%$. In Brazil, SCB is generated in large quantities as a residue of sugar production and first generation ethanol factories (more than 800 million tons of sugarcane processed in the $2014 / 2015^{\prime}$ crop) (UNICA, 2015). Considering this scenario and taking into account the environmental issues, scientific researches for new energy sources in Brazil have been focused on the use of SCB to obtain second generation ethanol and other value-add products.

For the production of second-generation ethanol from SCB, a step of pretreatment is necessary to remove or disrupt lignin and 
to decrease cellulose crystallinity. Subsequently, carbohydrates polymers have to be chemical or enzymatically saccharified into glucose, which finally will be converted to ethanol by fermentative microorganisms (Tomás-Pejó et al., 2011).

Ozonolysis was studied decades ago as a chemical oxidative pretreatment of lignocellulosic materials (Neely, 1984) and has been rediscovered recently (García-Cubero et al., 2010, 2012; Li et al., 2015; Travaini et al., 2013). Ozonolysis pretreatment promotes kinetic-selective degradation of lignin, because its high quantity of electron-rich centers prone to ozone attach. Ozone converts acid insoluble lignin (AIL) into acid soluble lignin (ASL) and low molecular weight compounds, mainly the carboxylic acids oxalic, formic and acetic. Lignin removal increases enzymes accessibility to polysaccharides and sugar release (Travaini et al., 2015). Among the many advantages of ozonolysis on other pretreatments, these can be highlighted: high saccharification yields; low inhibitory compounds formation; the process occurs at ambient pressure and temperature; a single solid phase is generated, avoiding problems related to products dilution; ozone can be generated in situ and residual ozone can be easily destroyed, preventing environmental problems (Travaini et al., 2016).

Enzymatic saccharification of lignocellulosic materials to obtain glucose requires the use of microbial enzymes cocktails comprising at least three hydrolases: endoglucanase, exoglucanase and $\beta$ glucosidase (Arantes and Saddler, 2010). These enzymes are produced by many microorganisms, especially filamentous fungi (Maeda et al., 2013). Among them, thermophilic fungi stand out, since they can use lignocellulosic wastes as substrates to produce enzymes by solid state fermentation (SSF). In general, they better support temperature rise, common in SSF processes, and produce more active and stable enzymes under high temperatures, compared to mesophilic fungi (Gomes et al., 2007).

The search for new microbial cellulases that can be produced by SSF, using lignocellulosic residues as substrates, is interesting to reduce the costs of second-generation ethanol production, since enzymatic saccharification is one of the most expensive steps in the global process. These enzymes must have some characteristics, such as: high hydrolysis rate; activity and stability at high temperatures; and low inhibition by end-product and by secondary compounds that could be generated in the process (Mielenz, 2001). All the works available in scientific literature related to enzymatic saccharification of lignocellulosic material pretreated with ozone use commercial cellulases (García-Cubero et al., 2009; Li et al., 2015; Travaini et al., 2013).

In this work, the enzymatic extract produced by SSF from the new isolated thermophilic fungus Myceliophthora thermophila JCP 1-4 was used to saccharify ozone pretreated SCB. This fungus shows significant production of cellulases when growing in a variety of lignocellulosic substrates, including avicelase, the enzyme responsible for hydrolysis of crystalline cellulose (Cassia Pereira et al., 2015). Glucose isomerase activity was also detected in the enzymatic extract, which is not usual in fungi. Commercial enzymes were also used for comparison purposes. The influence of time, temperature, enzyme and bagasse load in saccharification were evaluated. Enzyme activities were monitored along with saccharification, and the endurance of enzymes subjected to concentration using a rotary evaporator was also studied. Hydrolysates were fermented using a bakery strain of Saccharomyces cerevisiae to obtain ethanol.

\section{Methods}

\subsection{Sugarcane bagasse}

SCB was donated by Usina Vale, city of Onda Verde, São Paulo State, Brazil. It was washed with distilled water to remove sugar residues and particulate material, dried in a ventilated oven at $37{ }^{\circ} \mathrm{C}$ and ground in an agricultural crusher (Trapp Model TRF400 ) to a size of 3-5 mm. In natura SCB chemical composition (\%) was: $3.13 \pm 0.04$ of ASL, $19.54 \pm 0.03$ of AIL, $22.67 \pm 0.07$ of total lignin (TL), $20.86 \pm 0.05$ of xylan and $46.21 \pm 0.10$ of cellulose (Travaini et al., 2013).

\subsection{Ozonolysis pretreatment}

Pretreatment was carried out in a fixed bed reactor (glass column of $50 \mathrm{~cm}$ in height and $2.7 \mathrm{~cm}$ in diameter) provided with a porous glass diffuser, as described by Travaini et al. (2013). The optimal operation parameters found in the previously mentioned work were applied: moisture content of $80 \%$, ozone/oxygen concentration of $3.44 \%(\mathrm{~mol} / \mathrm{mol})$ at a flow of $60 \mathrm{~L} / \mathrm{h}$, for $45 \mathrm{~min}$. After pretreatment, SCB was washed with distilled water. Ozonated SCB chemical composition (\%) was: $6.22 \pm 0.07$ of ASL, $12.99 \pm 0.02$ of AIL, $19.20 \pm 0.09$ of TL, $20.74 \pm 0.12$ of xylan and $44.86 \pm 0.75$ of cellulose (Travaini et al., 2013).

\subsection{Microorganism}

The fungus $M$. thermophila JCP 1-4 was isolated from SCB silage piles in Potirendaba, São Paulo State, Brazil. It was chosen for the present study, among 26 thermophilic fungi, as the best producer of cellulases and $\beta$-glucosidase, when cultivated by SSF, at $45^{\circ} \mathrm{C}$, using a variety of lignocellulosic materials as substrates (Cassia Pereira et al., 2015). $\beta$-glucosidase from $M$. thermophila JCP $1-4$ is resistant to glucose inhibition (Cassia Pereira et al., 2015), an important characteristic for saccharification experiments. Stock cultures are maintained in cryo tubes, in $20 \%$ glycerol solution at $-80^{\circ} \mathrm{C}$.

\subsection{Enzymes production by solid state fermentation}

To obtain enzymatic extract, $M$. thermophila JCP 1-4 was precultivated on Sabouraud agar plates for $72 \mathrm{~h}$ at $45^{\circ} \mathrm{C}$. Five mycelial disks ( $1 \mathrm{~cm}$ diameter) from plates were used as inoculum for each $250 \mathrm{~mL}$ Erlenmeyer flask, containing $2.5 \mathrm{~g}$ of in natura SCB and $2.5 \mathrm{~g}$ of soybean meal (both washed and oven dried at $37^{\circ} \mathrm{C}$ ). Soybean meal was donated by Trouw Nutrition, Mirassol, São Paulo State, Brazil. Each Erlenmeyer flask was moisturized with $11 \mathrm{~mL}$ of saline solution as described by Toyama and Ogawa (1978), providing an initial substrate moisture close to $70 \%$. Erlenmeyer flasks with substrates and saline solution were autoclaved at $121^{\circ} \mathrm{C}$, $1 \mathrm{~atm}$, during $20 \mathrm{~min}$ before inoculation. Erlenmeyer flasks were inoculated and incubated at $45^{\circ} \mathrm{C}$, for $96 \mathrm{~h}$, time for a satisfactory cellulolytic enzymes production (Cassia Pereira et al., 2015). After this period, $50 \mathrm{~mL}$ of distilled water were added to each flask, the mixture was homogenized with a glass bar, stirred in an orbital shaker at $100 \mathrm{rpm}$ for $1 \mathrm{~h}$. Then, it was filtered through nylon cloth disks and centrifuged at $10,000 \mathrm{~g}$, for $15 \mathrm{~min}$, at $5^{\circ} \mathrm{C}$. Supernatants were collected, lyophilized and stored. For use, the enzymes were resuspended in water in the same water ratio of the original extract, for reproduce the same conditions when crude enzymes can be used. The enzymatic activities in the reconstituted extract were $0.33 \mathrm{FPU} / \mathrm{mL}$ and $1.00 \mathrm{CBU} / \mathrm{mL}$ ( $1: 3 \mathrm{FPU} / \mathrm{CBU}$ ratio, the same found in crude extract).

\subsection{Enzyme concentration}

Fungal enzymatic extract had to be concentrated for some of the saccharification experiments (those in which the influence of dry matter content was evaluated), in order to achieve the desired FPU per $g$ of cellulose. Concentration was performed by rotaevaporation, the extract was concentrated by 5 -fold (initial volume 
divided by final volume) on a rotatory evaporator at $60{ }^{\circ} \mathrm{C}$ under $100 \mathrm{rpm}$ in vacuum. Each concentration procedure took approximately $2 \mathrm{~h}$.

\subsection{Enzyme activities}

FPase activity was determined as described by Ghose (1987) and expressed as PFU. $\beta$-glucosidase activity was assayed according to Leite et al. (2008) and expressed as CBU. Endoglucanase and exoglucanase (avicelase) activities were determined as described by Cassia Pereira et al. (2015).

Glucose isomerase activity was determined according to Zhang et al. (2013), with modifications. Reaction tubes were composed of: $0.5 \mathrm{~mL}$ of $0.2 \mathrm{M}$ sodium phosphate buffer ( $\mathrm{pH}$ 7.0), $0.2 \mathrm{~mL}$ of $1 \mathrm{M}$ Dglucose, $0.1 \mathrm{~mL}$ of $0.1 \mathrm{M} \mathrm{MgSO}_{4} \cdot 7 \mathrm{H}_{2} \mathrm{O}, 0.1 \mathrm{~mL}$ of $0.01 \mathrm{M} \mathrm{CoCl}_{2} \cdot 6 \mathrm{H}_{2}-$ $\mathrm{O}, 0.9 \mathrm{~mL}$ of distilled water and $0.2 \mathrm{~mL}$ of crude enzymatic extract. Reaction tubes were incubated at 40,50 or $60^{\circ} \mathrm{C}$, for $1 \mathrm{~h}$, and then reaction was stopped by addition of $2 \mathrm{~mL} 0.5 \mathrm{M}$ perchloric acid. One unit of glucose isomerase activity was defined as the amount of enzyme needed to produce $1 \mu \mathrm{mol}$ of fructose per minute, under the assay conditions.

\subsection{Sugarcane bagasse enzymatic saccharification}

Saccharification assays were performed in $100 \mathrm{~mL}$ Erlenmeyer flasks containing in natura or ozone pretreated SCB $(3-10 \%, \mathrm{w} / \mathrm{w}$ dry basis) in sodium citrate buffer $0.05 \mathrm{M}, \mathrm{pH} 5.0$ and the desired load of FPU per $g$ of cellulose, provided by the enzymatic extract of $M$. thermophila JCP 1-4 or commercial enzymes, with $25 \mathrm{~mL}$ of final volume. The commercial enzymes used were Celluclast $1.5 \mathrm{~L}$ and Novozym 188 (Novozymes, Denmark). The first one was used as FPU source and the second as $\beta$-glucosidase source, to achieve the same FPU/CBU of $1: 3$ ratio found in the fungal enzymatic extract. Flasks were incubated on an orbital shaker, at different temperatures and $300 \mathrm{rpm}$, for up to $48 \mathrm{~h}$. Substrate blank experiments were performed without enzyme addition, using only bagasse and buffer solution. Enzyme blank experiments were performed without bagasse, only with enzyme and buffer solution. At each time interval, a flask was taken, cooled in an ice bath, its content was filtered using $0.22 \mu \mathrm{m}$ filters and sugars in the liquid fraction were determined and quantified by HPLC (high pressure liquid chromatography). The values of sugars $(\mathrm{g} / \mathrm{L})$ in blank experiments were subtracted from the values obtained in saccharification media. Yields were expressed as $g$ of glucose divided per $\mathrm{g}$ of cellulose in the raw material, multiplied by 100 (expressed as a percentage). Experiments were performed as duplicates.

\subsection{Statistical analysis}

The effects of temperature, time, enzyme load and dry matter in ozonated SCB saccharification by M. thermophila JCP 1-4 enzymes were evaluated, using a one-factor-at-a-time (OFAT) design of experiments.

Statistical analysis of the data from saccharification experiments included a one-way ANOVA followed by Tukeýs test with a $5 \%$ significance level. All analyses were run in the STATGRAPHICS ${ }^{\circledR}$ Centurion XVI Version 16.2.04 (64-bit).

\subsection{Alcoholic fermentation}

For preculture production, a fresh bakery strain of $S$. cerevisiae acquired in a grocery shop was grown on commercial YEPD (Yeast Extract Peptone Dextrose) (1\% yeast extract, 2\% peptone and 2\% glucose), aerobically, on a rotatory shaker at $30^{\circ} \mathrm{C}, 175 \mathrm{rpm}$, for $24 \mathrm{~h}$.
Hydrolysate slurries were transferred to $100 \mathrm{~mL}$ penicillin flasks, supplemented with $4 \mathrm{~g} / \mathrm{L}$ yeast extract, $2 \mathrm{~g} / \mathrm{L}\left(\mathrm{NH}_{4}\right)_{2} \mathrm{SO}_{4}$, $2 \mathrm{~g} / \mathrm{L} \mathrm{KH}_{2} \mathrm{PO}_{4}$ and $0.75 \mathrm{~g} / \mathrm{L} \mathrm{MgSO}{ }_{4} \cdot 7 \mathrm{H}_{2} \mathrm{O}$ and inoculated with $5.5 \%$ (v/v) of the preculture (Wanderley et al., 2013). Flasks were sealed and fermentation occurred with the oxygen present in the empty flask space, at $30^{\circ} \mathrm{C}$, under $175 \mathrm{rpm}$, for $24 \mathrm{~h}$. The supernatants were filtrated and analyzed by HPLC.

Ethanol yield was calculated with respect to the maximum theoretical production. Ethanol content $(\mathrm{g} / \mathrm{L})$ was divided by the glucose content $(\mathrm{g} / \mathrm{L})$, multiplied by the stoichiometric factor 0.511 , and then the value was multiplied by 100 to give the percentage.

\subsection{Analytical methods}

Ethanol analysis was performed using the same HPLC setup previously described by Toquero and Bolado (2014), equipped with a Biorad Aminex ${ }^{\circledR}$ HPX-87H column, with $0.6 \mathrm{~mL} / \mathrm{min}$ sulfuric acid $5 \mathrm{mM}$ as eluent, at $50{ }^{\circ} \mathrm{C}$. For sugars analysis, the system was equipped with a Phenomenex ${ }^{\circledR}$ HPLC column Rezex ${ }^{\mathrm{TM}}$ RPMMonosaccharide $\mathrm{Pb}^{+2}(8 \%), 300 \times 7.8 \mathrm{~mm}$, with $0.6 \mathrm{~mL} / \mathrm{min}$ MilliQ water as eluent, at $80^{\circ} \mathrm{C}$.

\section{Results and discussion}

\subsection{Saccharification of sugarcane bagasse using fungal or commercial enzymes}

In order to compare the efficiency of $M$. thermophila JCP 1-4 enzymatic extract in relation to the commercial enzymes mixture, preliminary saccharification assays were performed using in natura or ozonated SCB $\left(3 \% \mathrm{w} / \mathrm{w}\right.$ - dry basis, at $50{ }^{\circ} \mathrm{C}$, for $\left.24 \mathrm{~h}\right)$. The enzyme load used was $10 \mathrm{FPU}$ and $30 \mathrm{CBU}$ per $\mathrm{g}$ of cellulose content in raw material, for both fungal and commercial enzymes. These conditions are commonly cited in studies about sugarcane enzymatic saccharification (Cassia Pereira et al., 2015; Travaini et al., 2013). Besides, $50^{\circ} \mathrm{C}$ is the optimum temperature for the commercial enzymes activities, and the enzymatic extract from $M$. thermophila JCP 1-4 shows good activities of endoglucanase, exoglucanase, $\beta$-glucosidase and FPase under this temperature (55.16, 2.01, $1.02 \mathrm{U} / \mathrm{mL}$ and $0.51 \mathrm{FPU}$, respectively).

As shown in Table 1, for in natura SCB, fungal enzymatic extract provided a glucose release of approximately 1.4 folds higher than commercial enzymes. Xylose release from in natura SCB was also higher (3.9 folds) when using $M$. thermophila JCP 1-4 enzymes. Regarding cellobiose release from in natura bagasse, very close values were obtained when using fungal or commercial enzymes. A standard one-way ANOVA analysis indicated significant differences in glucose release when using MT or commercial enzymes to saccharify in natura SCB $(F=213.2$ and $p$-value $=0.003)$.

Table 1

Sugars released from in natura and ozonated bagasse, in saccharification assays (3\% $\mathrm{w} / \mathrm{w}$ dry basis, $10 \mathrm{FPU}$ and $30 \mathrm{CBU}$ per $\mathrm{g}$ of cellulose, $50^{\circ} \mathrm{C}, 24 \mathrm{~h}$ ) using Myceliophthora thermophila JCP 1-4 enzymatic extract (MT) or commercial enzymes*.

\begin{tabular}{lllll}
\hline Enzyme source & SCB & \multicolumn{2}{l}{ Sugar $(\mathrm{g} / \mathrm{L})^{* *}$} & \\
\cline { 3 - 5 } & & Glucose $^{* * *}$ & Xylose & Cellobiose \\
\hline MT & In natura & $1.40 \pm 0.02$ & $0.50 \pm 0.02$ & $0.15 \pm 0.04$ \\
Commercial & & $0.95 \pm 0.20$ & $0.13 \pm 0.16$ & $0.18 \pm 0.01$ \\
MT & Ozonated & $4.19 \pm 0.02$ & $1.94 \pm 0.02$ & $0.23 \pm 0.05$ \\
Commercial & & $4.13 \pm 0.20$ & $1.08 \pm 0.44$ & $0.04 \pm 0.00$ \\
\hline
\end{tabular}

\footnotetext{
Mixture of Celluclast $1.5 \mathrm{~L}$ and Novozym 188.

No sugars were detected in the substrate blank and enzyme blank under the HPLC method limit of detection $(>0.01 \mathrm{~g} / \mathrm{L})$.

${ }_{* * * *}$ No significant difference found on sugar released applying one-way ANOVA analysis $(p<0.005)$, using ozonated SCB saccharified with MT or commercial enzymes.
} 
However, there was no significant difference in glucose release from ozonated SCB when using MT or commercial enzymes $(F=0.106$ and $p$-value $=0.8)$.

Regarding ozonated SCB, the use of fungal enzymes provided a glucose release very close to that observed when using the commercial ones, and release of xylose and cellobiose $44 \%$ and $83 \%$ higher, respectively. These data clearly show the efficiency of fungal enzymes to saccharify ozonated SCB. Furthermore, ozone pretreatment improved the releasing of reducing sugars in saccharification for both enzymes.

From these results, further ozone pretreated SCB saccharification experiments were performed using the enzymatic extract from $M$. thermophila JCP 1-4. Works dealing with the use of noncommercial microbial enzymes to saccharify ozonated SCB or other pretreated lignocellulosic materials are scarce in literature. Besides, the use of new microbial enzymes with appropriate characteristics for lignocellulosic material saccharification can greatly cheapen biorefineries processes.

\subsection{Influence of temperature and time on saccharification of ozonated bagasse}

Saccharification assays were performed at 40,50 and $60^{\circ} \mathrm{C}$ (temperatures around the optimal for commercial enzymes), using 3\% (w/w, dry basis) ozonated SCB. M. thermophila JCP 1-4 enzymatic extract was loaded for $10 \mathrm{FPU}$ and $30 \mathrm{CBU}$ per $\mathrm{g}$ of cellulose content in the raw material and samples were taken at different time intervals.

Glucose release increased with the increasing of temperature (Fig. 1a). The higher release of this sugar $(5.38 \mathrm{~g} / \mathrm{L} ; 39 \%$ yield) was observed at $48 \mathrm{~h}$ and $60^{\circ} \mathrm{C}$. Additionally, at this temperature, a glucose release of $4.99 \mathrm{~g} / \mathrm{L}$ (36\% yield) was obtained at only $8 \mathrm{~h}$ of saccharification, which can be considered a satisfactory sugar release in a short hydrolysis time, indicating that it is not advantageous to extend the experiment. The profiles of glucose releasing at 40 and $50^{\circ} \mathrm{C}$ were similar, and the amount of glucose release tends to stabilize after $16 \mathrm{~h}$ of saccharification (around $4.0 \mathrm{~g} / \mathrm{L}$ ). A very close glucose yield (41.79\%) was obtained by Travaini et al. (2013) with ozonated SCB produced in identical conditions of this work, using the commercial enzymes NS50013 and NS50010 (from Novozymes) during $24 \mathrm{~h}$ saccharification at $50{ }^{\circ} \mathrm{C}$. Souza-Correa et al. (2013, 2014), working with ozonated SCB achieved cellulose-to-glucose conversions between $65 \%$ and $78.8 \%$; however they used different ozonolysis conditions, 20 FPU per $g$ of substrate and worked with just $1 \%$ of substrate concentration, during $24 \mathrm{~h}$ at $50{ }^{\circ} \mathrm{C}$.

Surprisingly, fructose was also detected in hydrolysates (Fig. 1b) but not in the fungal enzymatic extract and even in substrate chemical composition, which was considered an indicative that $M$. thermophila JCP 1-4 produced a glucose isomerase. To confirm this hypothesis, glucose isomerase activity in the enzymatic extract was determined at 40,50 and $60^{\circ} \mathrm{C}$. It is a rare characteristic, since glucose isomerase (responsible for glucose isomerization into fructose) is hardly found among fungi. The traditional glucose isomerase source are bacteria, and its production was also reported for some basidiomycetes (Horwath and Irbe, 1984), but there is no report in literature about this enzyme production by other fungi.

Relationship between temperature of saccharification and fructose release was opposite to that observed for glucose (Fig. 1b). The highest amount of fructose $(1.40 \mathrm{~g} / \mathrm{L})$ was obtained after $48 \mathrm{~h}$, at $40{ }^{\circ} \mathrm{C}$. Again, from $8 \mathrm{~h}$ on very close amounts were obtained. Glucose isomerase activity was measured in fungal enzymatic extract. From these data it can be inferred that, during the saccharification, part of the glucose content was converted to fructose by the action of glucose isomerase, avoiding $\beta$-glucosidase inhibition and, consequently, increasing the conversion of cellobiose to glucose (Fig. 1).
Enzyme activities at 40,50 and $60{ }^{\circ} \mathrm{C}$ were $0.36,0.31$ and $0.23 \mathrm{U} / \mathrm{mL}$, respectively. Thus, fructose production is directly related to glucose isomerase enzymatic activity, since both decreased with the increasing of temperature. It is worth to note that in the chemical characterization of SCB it was not observed the presence of fructose, which can only have arisen from glucose conversion.

Cellobiose concentration initially increased, increasing the kinetic with temperature, but decreased after around $16 \mathrm{~h}$ saccharification time (Fig. 1c).

After defining the most suitable condition for saccharification, based on glucose release $\left(8 \mathrm{~h}\right.$ and $\left.60^{\circ} \mathrm{C}\right)$, new experiments were performed, in order to evaluate the efficiency of commercial enzymes after $8 \mathrm{~h}$ saccharification at $60^{\circ} \mathrm{C}$ and at the optimum temperature of the commercial enzymes $\left(50^{\circ} \mathrm{C}\right)$. At $60^{\circ} \mathrm{C}, \mathrm{M}$. thermophila JCP 1-4 enzymes provided a glucose release around $30 \%$ higher when compared to commercial enzymes mixture (4.99 and $3.50 \mathrm{~g} / \mathrm{L}$, respectively). It is interesting to observe that the saccharification efficiency of commercial enzymes at 50 and $60{ }^{\circ} \mathrm{C}$ was very close (glucose release of 3.62 and $3.50 \mathrm{~g} / \mathrm{L}$, respectively), which indicates that at $60^{\circ} \mathrm{C}$ their activity is not being considerably reduced.

\subsection{Monitoring fungal enzymes activities during enzymatic saccharification}

FPase and $\beta$-glucosidase activities of fungal extract were monitored during saccharification experiments. Results discussed below are presented as percentage relative to the enzymatic activity measured at zero time in the saccharification media. Enzymatic extract was loaded at saccharification media to achieve 0.14 FPU and $0.42 \mathrm{CBU} / \mathrm{mL}$ in the final volume (corresponding to $10 \mathrm{FPU}$ and 30 CBU by $g$ of cellulose content in raw SCB). Identical or very similar enzymatic activities were obtained from the measurements at time zero in the saccharification media (ANOVA analysis showed no-significant differences, and so, these data are not shown).

Initially, an experiment using in natura SCB at $3 \%(\mathrm{w} / \mathrm{w}$, dry basis) as substrate and an enzyme blank experiment containing only buffer and enzymatic extract were conducted, at $50^{\circ} \mathrm{C}$ (enzyme load as described in Section 3.2). In the enzyme blank experiment, FPase activity decreased clearly with time, retaining around $70 \%$ of its original activity between 16 and $24 \mathrm{~h}$ (Fig. 2a). Regarding $\beta$-glucosidase activity (Fig. 2b), a slight increase was observed during the first $8 \mathrm{~h}$ (around 5\%) and the enzyme retained $100 \%$ of its original activity until $16 \mathrm{~h}$. At $24 \mathrm{~h}, \beta$-glucosidase activity decreased only $7.5 \%$, indicating that this enzyme is more stable than FPase. Activities of FPase and $\beta$-glucosidase were improved slightly in the experiment with in natura bagasse (11\% and $10 \%$ higher when compared to their original activities, at 8 and $24 \mathrm{~h}$ of saccharification, respectively) (Fig. 2a and b). Bagasse seems to weakly stimulate the enzymatic activity of both enzymes from the fungal extract.

FPase and $\beta$-glucosidase activities were also monitored in the saccharification experiment using ozonated bagasse (described in Section 3.2). A remarkable increase of enzymatic activities was observed during the saccharification course. The most outstanding increases in FPase activity were observed in $48 \mathrm{~h}$ at 50 and $60^{\circ} \mathrm{C}$ ( $284 \%$ and $274 \%$, respectively) (Fig. 2c). Concerning $\beta$-glucosidase, it can be highlighted a maximum increase of $269.93 \%$ in $48 \mathrm{~h}$, at $50{ }^{\circ} \mathrm{C}$ (Fig. 2d). This considerable increase in enzyme activities was not related to an increase in glucose release. Glucose release increased very slightly after $8 \mathrm{~h}$ of saccharification, probably because there were no more polysaccharides suitable for conversion or due to some complex enzymatic inhibition process. From these results, lignocellulose structure breakdown by pretreatment seems to be the limiting step of the global process. Nevertheless, 


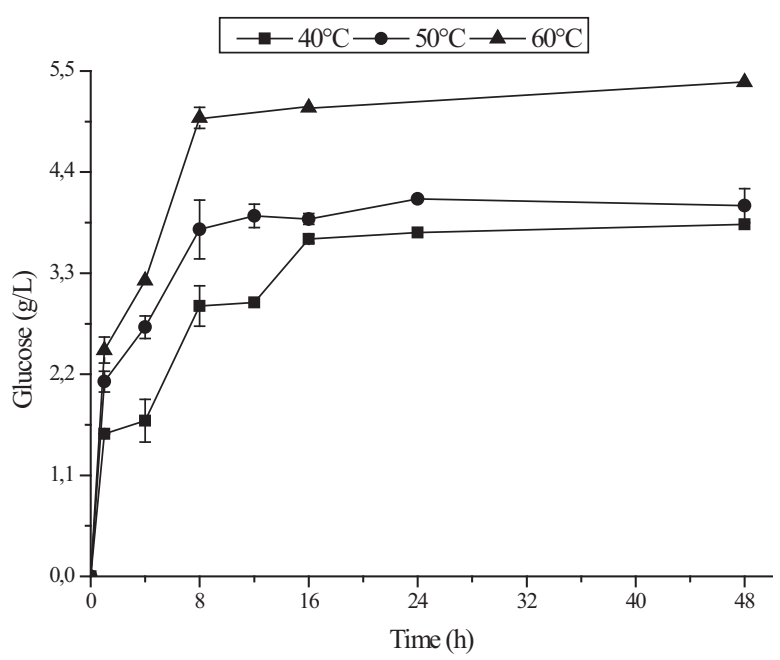

(a)

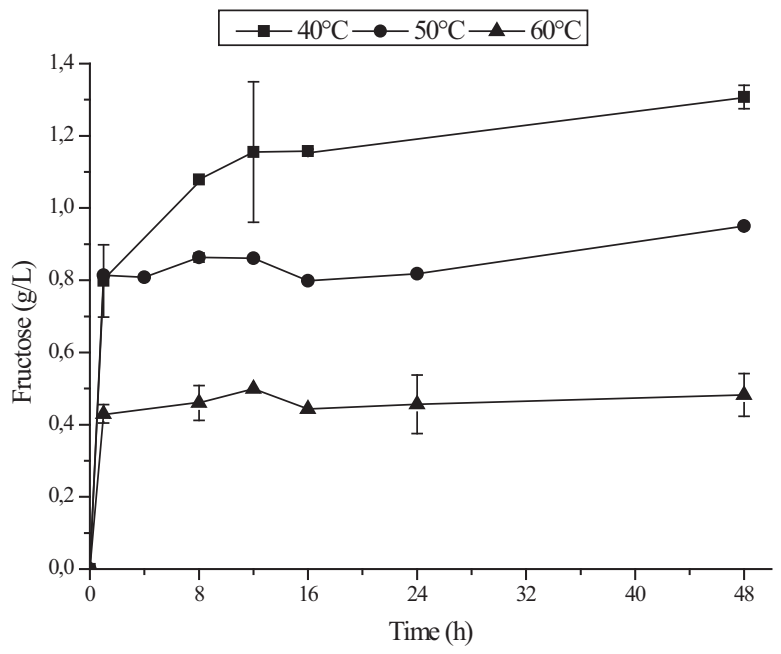

(b)

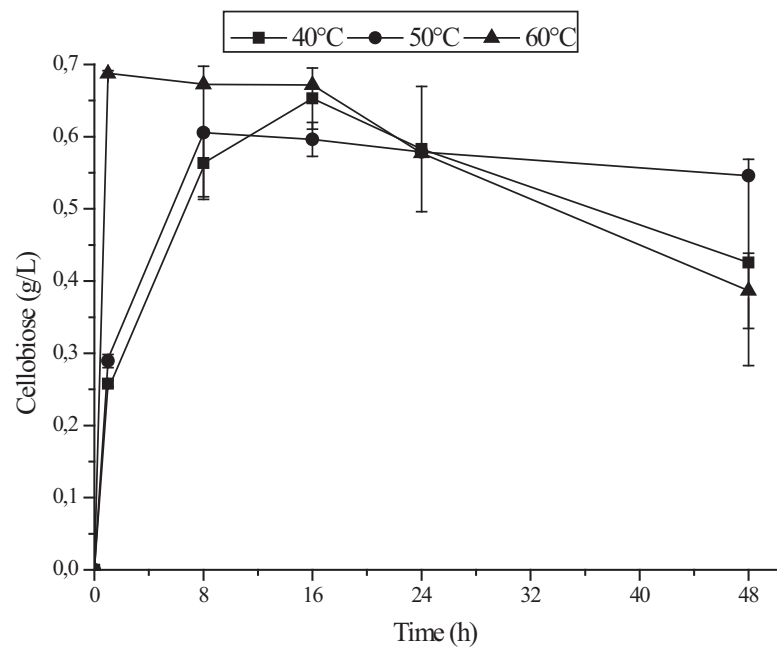

(c)

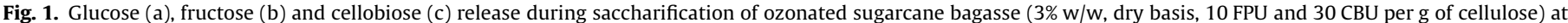
different temperatures. Enzymes provided from Myceliophthora thermophile JCP 1-4.

the enzymatic activity increases could be very interesting when using other pretreatments.

Fructose has been described as a stabilizer of $\beta$-glucosidase activity (Weijers and Van't Riet, 1992). Since fructose was produced during saccharification by the action of glucose isomerase, the activities of FPase $\beta$-glucosidase in the enzymatic extract from $M$. thermophila JCP 1-4 were measured, at $50^{\circ} \mathrm{C}$, in the presence of this sugar. Fructose was added to the assay tubes at $0.95 \mathrm{~g} / \mathrm{L}$ (the concentration found when the highest FPase and $\beta$-glucosidase activities increases were observed). In this assays, practically no increase was found on FPase activity. On the other hand, $\beta$ glucosidase activity was increased by $180 \%$ in the presence of fructose. These results suggest that fructose exerts specific activation effect on $\beta$-glucosidase activity. However, the increase in $\beta$ glucosidase activity may improve FPase action in a global view, since it removes cellobiose from media, reducing its inhibitory effect on cellulases.

The fructose effect is not enough to explain the observed increase on FPase and $\beta$-glucosidase activities during ozonated bagasse saccharification experiments. Increase on enzymatic activ- ities are higher for ozonated SCB than for in natura SCB in all the experiments. Enzymatic activities decreased since time zero, as expected, for enzyme blank experiments without substrate. The lower increase in enzyme activation and activity retention in time found for in natura SCB can be attributed to enzymes active site protection and protein rearrangement (Kokkinidis et al., 2012). Since the increase on these enzymes activities was low during in natura bagasse saccharification experiments, we can infer that some compound(s) produced or released after ozonolysis pretreatment could have a more expressive effect on their activities. Apart from fructose, other factors may contribute to enzymatic activation, such as ions, which can act as cofactors helping to maintain the structure of polymeric proteins and also stabilizing active sites (Hernández-Salas et al., 2009; Iyer and Ananthanarayan, 2008).

\subsection{Influence of enzyme load in ozonated SCB saccharification}

Working with the best conditions of time and temperature ( $8 \mathrm{~h}$ at $\left.60{ }^{\circ} \mathrm{C}\right)$ for enzymatic ozonated SCB $(3 \% \mathrm{w} / \mathrm{w}$, dry basis) saccharification found in Section 3.2, the influence of enzyme load was 


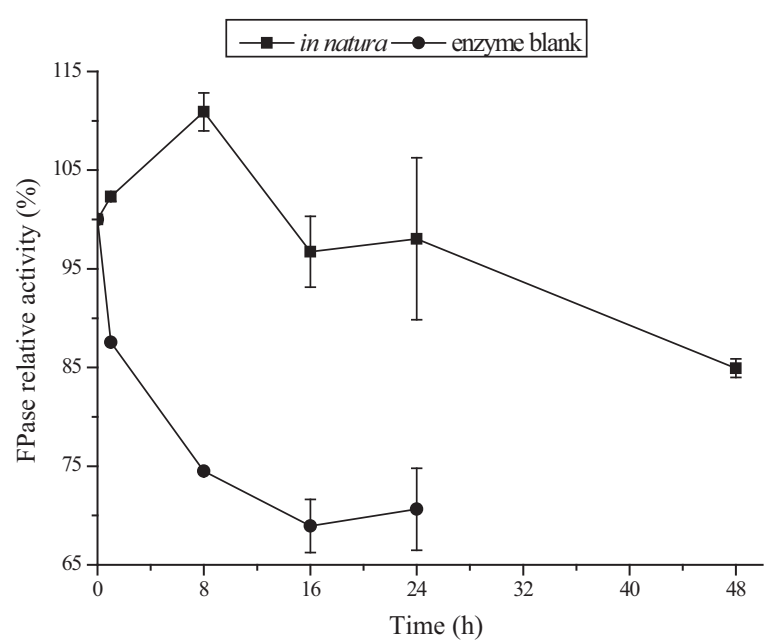

(a)

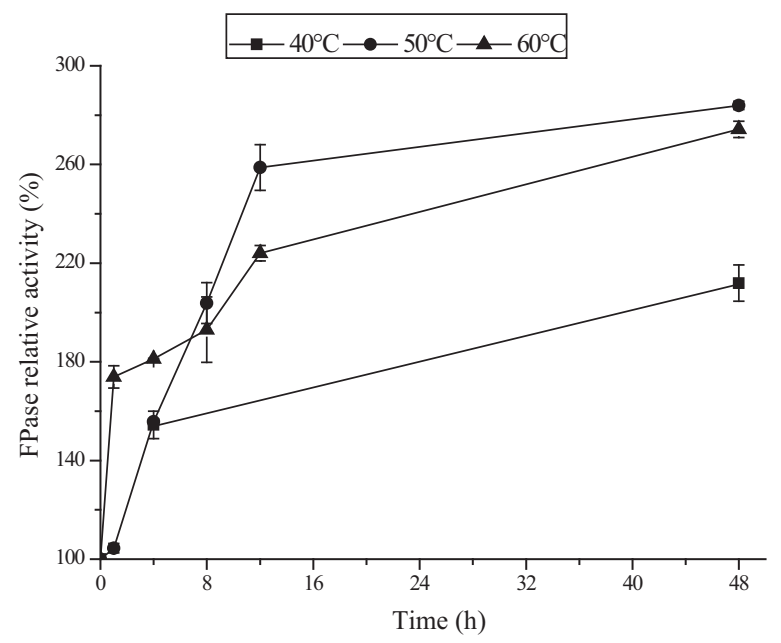

(c)

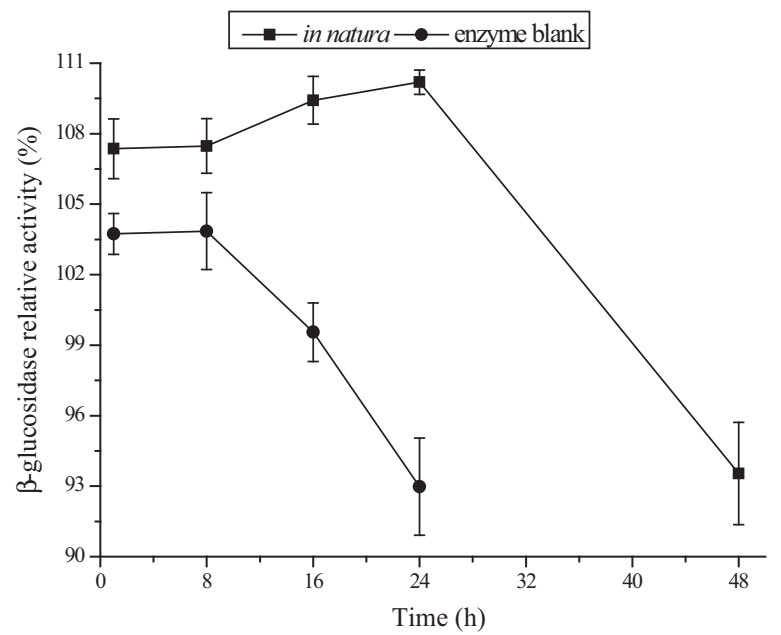

(b)

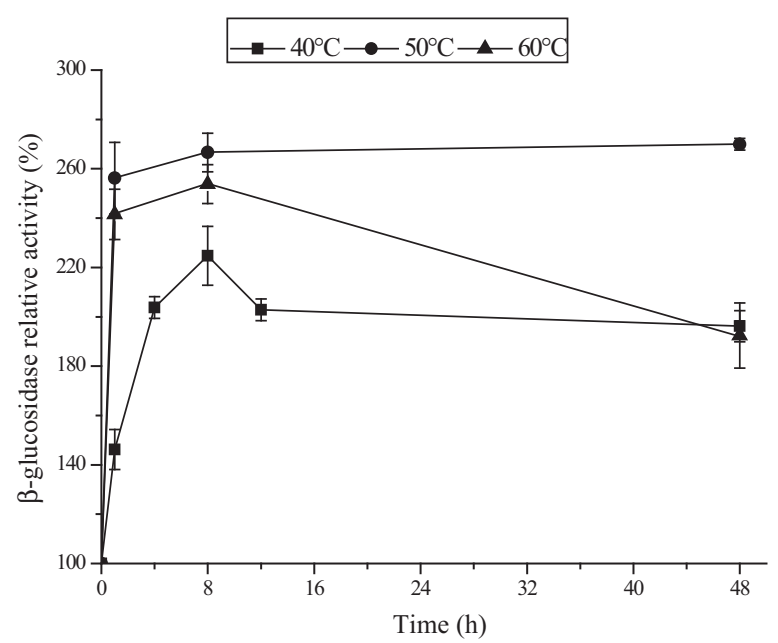

(d)

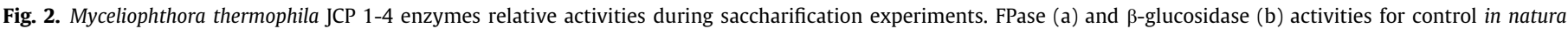

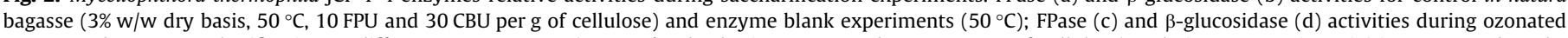

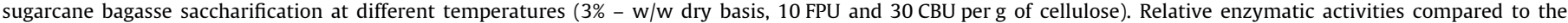
activities at zero time in saccharification media (0.14 FPU and $0.42 \mathrm{CBU} / \mathrm{mL}$, in the final volume to achieve $10 \mathrm{FPU}$ and $30 \mathrm{CBU}$ per $\mathrm{g}$ of cellulose content in SCB).

evaluated using the enzymatic extract from $M$. thermophila JCP 1-4 with basis on FPU. Enzyme loads in the range from 2.5 to $15 \mathrm{FPU}-$ per $g$ of cellulose were used. Glucose release markedly increased with enzyme loads up to $7.5 \mathrm{FPU}$ per $\mathrm{g}$ of cellulose $(4.86 \mathrm{~g} / \mathrm{L})$ (Fig. 3). Higher enzyme loads provided very slight increases on glucose release (5.21 g/L using 15 FPU per g of glucose). This enzyme load (7.5 FPU per $g$ of cellulose) is lower than other cited by scientific literature for SCB saccharification: 10 FPU per $g$ of cellulose (Travaini et al., 2013; Wanderley et al., 2013); 15 FPU per g of cellulose (Aguiar Souza et al., 2013; Mesa et al., 2011); 20 FPU per g of cellulose (Hongdan et al., 2013); and even values notably higher, such as 60 and 65 FPU per g of cellulose (Benjamin et al., 2013; Jiang et al., 2013).

It is well known that high enzyme loads increase glucose release during saccharification, however this is one of the most expensive steps in second-generation fuels production and in biorefineries factories. Thus, studies involving new microbial enzymes that present characteristics suitable for lignocellulosic material saccharification (high saccharification efficiency with low enzyme load, low product inhibition and stability during saccharification) are necessary.

\subsection{Influence of dry matter content in ozonated SCB enzymatic saccharification and hydrolysates fermentation}

The amount of dry matter is an important parameter in the study of enzymatic saccharification, since it refers to the amount of substrate to be converted by enzymes which, in turns, is related to the final hydrolysate sugar concentration, including fermentable sugars.

To achieve the desired FPU per $\mathrm{g}$ of cellulose in experiments with high dry matter concentration, a previous fungal enzymatic extract concentration was required. For this purpose, the fungal extract was concentrated 5 times by rotaevaporation $\left(60{ }^{\circ} \mathrm{C}\right.$ and $100 \mathrm{rpm}$, in vacuum, for $2 \mathrm{~h}$ ). FPase and $\beta$-glucosidase activities were measured after concentration. Enzymes retained $90 \%$ and $64 \%$ of their original activities, respectively, providing a FBU/CBU ratio of $1: 2.15$ in the concentrated extract.

Saccharification experiments were performed at $60^{\circ} \mathrm{C}, 8 \mathrm{~h}$ and 7.5 FPU per $g$ of cellulose (the best conditions found in Sections 3.2 and 3.4), varying the amount of ozonated SCB in the range from $3 \%$ to $10 \%$ (w/w, dry basis). Results, in terms of glucose release and yield, are shown in Fig. 4. As expected, 10\% of bagasse provided the 


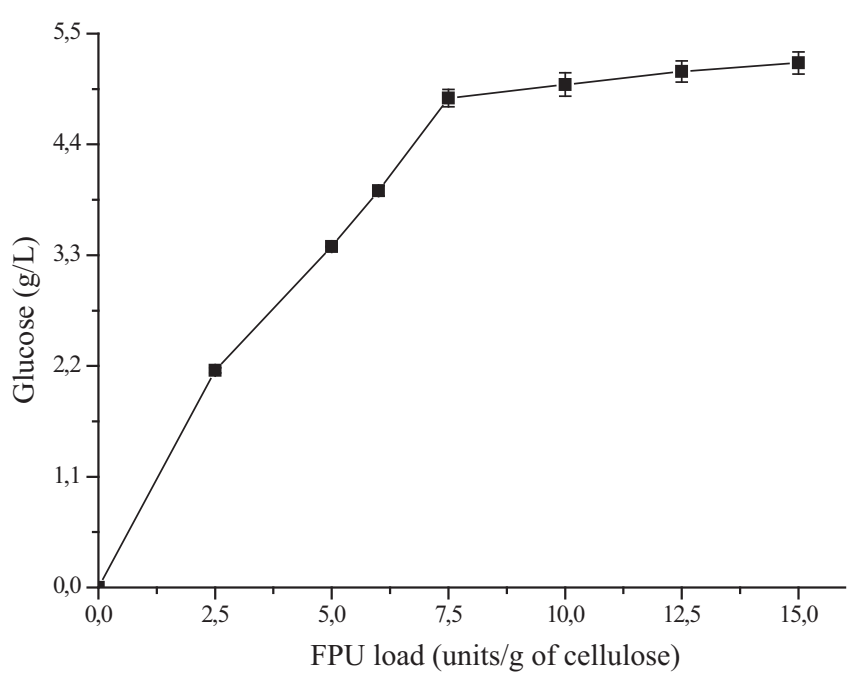

Fig. 3. Influence of enzyme load (FPU per g of cellulose) on glucose release from ozonated sugarcane bagasse in saccharification at $60^{\circ} \mathrm{C}, 3 \%(\mathrm{w} / \mathrm{w}$ dry basis) during $8 \mathrm{~h}$. Enzymes provided from Myceliophthora thermophila JCP $1-4$, with a ratio FPU: CBU of $1: 3$.

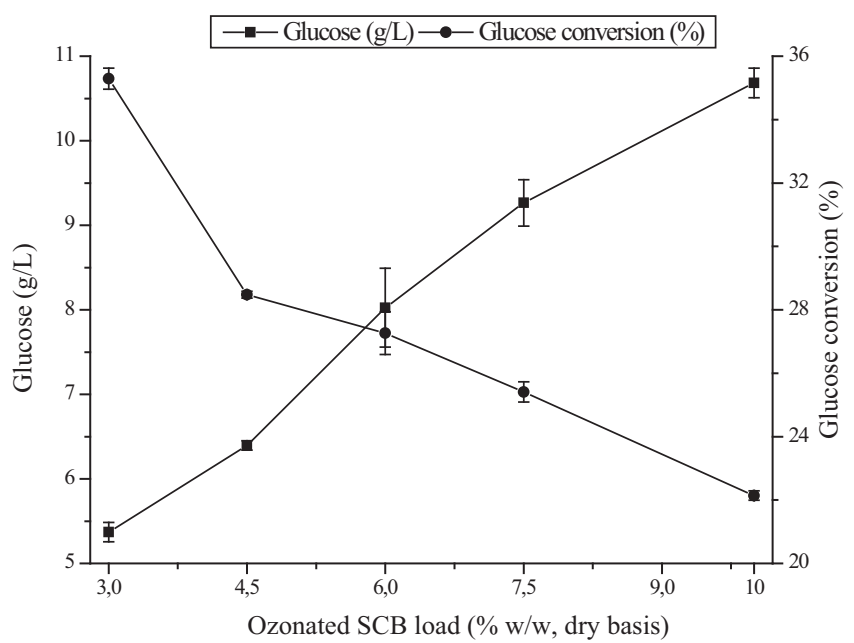

Fig. 4. Influence of dry matter content (\% w/w dry basis) on glucose release (g/L) and glucose conversion from ozonated sugarcane bagasse in saccharification at $60^{\circ} \mathrm{C}, 7.5 \mathrm{FPU}$ and $15.1 \mathrm{CBU}$ per $\mathrm{g}$ of cellulose, at $8 \mathrm{~h}$. Enzymes provided from Myceliophthora thermophila JCP 1-4.

highest glucose release $(10.19 \mathrm{~g} / \mathrm{L})$. Nevertheless, in terms of saccharification yield, the best result $(30.11 \%)$ was obtained with $3 \%$ of ozonated SCB. Maitan-Alfenas et al. (2015) worked with 8\% (w/v, dry basis) acid and basic pretreated SCB for saccharification with 5-fold concentrated fungal extract of Chrysophorte cubensis. They achieved $5.32 \mathrm{~g} / \mathrm{L}$ (12.5\% yield) and $2.94 \mathrm{~g} / \mathrm{L}$ (7.7\% yield) of glucose, respectively, for each pretreatment. However, they used 10 FPU per $g$ of dry pretreated SCB and $72 \mathrm{~h}$ of saccharification at $50{ }^{\circ} \mathrm{C}$.

High solid loads in saccharification may confer advantages and disadvantages and require an accurate analysis. A higher solid load provides higher glucose concentration after hydrolysis, increasing fermentation yield and reducing the costs related to the hydrolysate concentration. However, high solid loads usually bring lower enzymatic hydrolysis yields, due to some main factors: (1) increase on the dry matter concentration hinders the mass transfer and enzymes accessibility to biomass, being necessary higher stirring power and (2) high dry matter concentration leads to liquid absorption, resulting in a decrease of free water, reducing medium viscosity. Water is essential for hydrolysis reactions and necessary for solubilization. So, the increase on dry matter concentration can increase the process energy requirements and the production costs (Modenbach and Nokes, 2013).

\subsection{Alcoholic fermentation}

There is no previously published data about alcoholic fermentation of hydrolysates obtained from the saccharification of ozonated SCB. In order to test its fermentability, hydrolysates produced with fungal enzymes were fermented. Whole slurry hydrolysates from saccharification assays performed with 7.5 and $10 \%$ (w/w - dry basis) ozonated SCB were fermented with $S$. cerevisiae bakery strain to obtain ethanol. The $7.5 \%(\mathrm{w} / \mathrm{w})$ dry matter hydrolysate provided $2.81 \mathrm{~g} / \mathrm{L}$ of ethanol from $8.77 \mathrm{~g} / \mathrm{L}$ of glucose $(63 \%$ of the maximum theoretical conversion), whereas the $10 \%(\mathrm{w} / \mathrm{w})$ dry matter hydrolysate gave $3.15 \mathrm{~g} / \mathrm{L}$ of ethanol from $10.19 \mathrm{~g} / \mathrm{L}$ (61\% of the maximum theoretical conversion). Both fermentation yields are really close, indicating the absence of inhibitory compounds that could have been accumulated by high solids content. Wanderley et al. (2013) obtained 46.47\% (5.33 g/L) of ethanol efficiency using enzymatic hydrolysates in the same conditions of biomass load, but using commercial enzymes.

\section{Conclusions}

M. thermophila JCP 1-4 is a promising fungus for bioethanol production. Its enzymes efficiency to saccharify ozonated SCB was higher than that of the commercial enzymes used and increased with temperature. Fructose was found in hydrolysates, indicating glucose isomerase production (rare among fungi). Ozonated bagasse increased FPase and $\beta$-glucosidase activities during saccharification, suggesting that pretreatment is the limiting step. The evaluated saccharification parameters influenced sugars release: optimal results were obtained at $60^{\circ} \mathrm{C}$, with low enzyme load (7.5 FPU), in only $8 \mathrm{~h}$. Glucose released was converted into ethanol with a satisfactory yield, indicating no fermentation inhibition.

\section{Acknowledgements}

This work was supported by the "Fundação de Amparo à Pesquisa do Estado de São Paulo - FAPESP”, Brazil (2011/19554-0) and by the research unit UIC 071 of the regional government "Junta de Castilla y León - JCyL", Spain. Josiani de Cassia Pereira thanks to "Fundação de Amparo à Pesquisa do Estado de São Paulo - FAPESP", Brazil for her Master Scholarship (2011/12794-6) and for the internship scholarship "Bolsa Estágio de Pesquisa no Exterior - BEPE" (2012/20403), which allowed her to develop this work at the University of Valladolid. Rodolfo Travaini is also grateful to "Conselho Nacional de Desenvolvimento Científico e Tecnológico - CNPq", Brazil (238059/2012-0) for providing his Doctorate Scholarship.

\section{References}

Aguiar Souza, R., Silveira, M.H.L., Pitarelo, A.P., Corazza, M.L., Ramos, L.P., 2013. Kinetics of enzyme-catalyzed hydrolysis of steam-exploded sugarcane bagasse. Bioresour. Technol. 147, 416-423.

Arantes, V., Saddler, J.N., 2010. Access to cellulose limits the efficiency of enzymatic hydrolysis: the role of amorphogenesis. Biotechnol. Biofuels 3, 4 .

Benjamin, Y., Cheng, H., Görgens, J.F., 2013. Evaluation of bagasse from different varieties of sugarcane by dilute acid pretreatment and enzymatic hydrolysis. Ind. Crops Prod. 51, 7-18.

Cassia Pereira, J., Paganini Marques, N., Rodrigues, A., Brito de Oliveira, T., Boscolo, M., Da-Silva, R., Gomes, E., Bocchini Martin, D., 2015. Thermophilic fungi as new 
sources for production of cellulases and xylanases with potential. J. Appl. Microbiol. 118, 928-939.

García-Cubero, M., Coca, M., Bolado, S., González-Benito, G., 2010. Chemica oxidation with ozone as pre-treatment of lignocellulosic materials for bioethanol production. Chem. Eng. Trans. 21, 1273-1278.

García-Cubero, M.T., González-Benito, G., Indacoechea, I., Coca, M., Bolado, S., 2009. Effect of ozonolysis pretreatment on enzymatic digestibility of wheat and rye straw. Bioresour. Technol. 100, 1608-1613.

García-Cubero, M.T., Palacín, L.G., González-Benito, G., Bolado, S., Lucas, S., Coca, M. 2012. An analysis of lignin removal in a fixed bed reactor by reaction of cereal straws with ozone. Bioresour. Technol. 107, 229-234.

Ghose, T.K., 1987. Measurement of cellulase activities. Pure Appl. Chem. 59, 257 268.

Gomes, E., Guez, M.A.U., Martin, N., da Silva, R., 2007. Enzimas termoestáveis fontes, produção e aplicação industrial. Quim. Nova 30, 136-145.

Hernández-Salas, J.M., Villa-Ramírez, M.S., Veloz-Rendón, J.S., Rivera-Hernández, K. N., González-César, R.A., Plascencia-Espinosa, M.A., Trejo-Estrada, S.R., 2009 Comparative hydrolysis and fermentation of sugarcane and agave bagasse. Bioresour. Technol. 100, 1238-1245.

Hongdan, Z., Shaohua, X., Shubin, W., 2013. Enhancement of enzymatic saccharification of sugarcane bagasse by liquid hot water pretreatment. Bioresour. Technol. 143, 391-396.

Horwath, R., Irbe, R., 1984. Glucose isomerase from fungi of the basidiomycetes class. Patent Number US4447531A.

Iyer, P.V., Ananthanarayan, L., 2008. Enzyme stability and stabilization-aqueous and non-aqueous environment. Process Biochem. 43, 1019-1032.

Jiang, L.Q., Fang, Z., Li, X.K., Luo, J., Fan, S.P., 2013. Combination of dilute acid and ionic liquid pretreatments of sugarcane bagasse for glucose by enzymatic hydrolysis. Process Biochem. 48, 1942-1946.

Kokkinidis, M., Glykos, N.M., Fadouloglou, V.E., 2012. Protein Flexibility and Enzymatic Catalysis. In: Donev, R. (Ed.), Advances in protein chemistry and structural biology. Elsevier, USA, pp. 181-218.

Leite, R.S.R. Alves-Prado, H.F., Cabral, H., Pagnocca, F.C., Gomes, E., Da-Silva, R. 2008. Production and characteristics comparison of crude $\beta$-glucosidases produced by microorganisms Thermoascus aurantiacus e Aureobasidium pullulans in agricultural wastes. Enzyme Microb. Technol. 43, 391-395.

Li, C., Wang, L., Chen, Z., Li, Y., Wang, R., Luo, X., Cai, G., Li, Y., Yu, O., Lu, J., 2015. Ozonolysis pretreatment of maize stover: the interactive effect of sample particle size and moisture on ozonolysis process. Bioresour. Technol. 183, 240247.

Maeda, R.N., Barcelos, C.A., Anna, L.M.M.S., Pereira, N., 2013. Cellulase production by Penicillium funiculosum and its application in the hydrolysis of sugar cane bagasse for second generation ethanol production by fed batch operation. J. Biotechnol. 163, 38-44.

Maitan-Alfenas, G.P., Visser, E.M., Alfenas, R.F., Nogueira, B.R.G., de Campos, G.G. Milagres, A.F., de Vries, R.P., Guimarães, V.M., 2015. The influence of pretreatment methods on saccharification of sugarcane bagasse by an enzyme extract from Chrysoporthe cubensis and commercial cocktails: a comparative study. Bioresour. Technol. 192, 670-676.
Mesa, L., González, E., Romero, I., Ruiz, E., Cara, C., Castro, E., 2011. Comparison of process configurations for ethanol production from two-step pretreated sugarcane bagasse. Chem. Eng. J. 175, 185-191.

Mielenz, J.R., 2001. Ethanol production from biomass: technology and commercialization status. Curr. Opin. Microbiol. 4, 324-329.

Modenbach, A., Nokes, S.E., 2013. Enzymatic hydrolysis of biomass at high-solids loadings - a review. Biomass Bioenergy 56, 526-544.

Neely, W.C., 1984. Factors affecting the pretreatment of biomass with gaseous ozone. Biotechnol. Bioeng. 26, 59-65.

Souza-Correa, J.A., Oliveira, C., Wolf, L.D., Nascimento, V.M., Rocha, J.G.M., Amorim, J., 2013. Atmospheric pressure plasma pretreatment of sugarcane bagasse: the influence of moisture in the ozonation process. Appl. Biochem. Biotechnol. 171, 104-116.

Souza-Correa, J.A., Oliveira, C., Nascimento, V.M., Wolf, L.D., Gómez, E.O., Rocha, G.J. M., Amorim, J., 2014. Atmospheric pressure plasma pretreatment of sugarcane bagasse: the influence of biomass particle size in the ozonation process. Appl Biochem. Biotechnol. 172, 1663-1672.

Tomás-Pejó, E., Alvira, P., Ballesteros, M., Negro, M.J., 2011. Chapter 7 Pretreatment Technologies for Lignocellulose-to-Bioethanol Conversion. In: Pandey, A., Larroche, C., Ricke, S.C., Dussap, C.-G., Gnansounou, E. (Eds.), Biofuels. Elsevier, USA, pp. 149-176.

Toquero, C., Bolado, S., 2014. Effect of four pretreatments on enzymatic hydrolysis and ethanol fermentation of wheat straw. Influence of inhibitors and washing. Bioresour. Technol. 157, 68-76.

Toyama, N., Ogawa, K., 1978. Cellulase production of trichoderma viride in solid and submerged culture methods. In: Ghose, T. (Ed.), International Symposium on Bioconversion of Cellulosic Substances into Energy Chemicals and Microbial Proteins, pp. 305-312, New Delhi, India.

Travaini, R., Marangon-Jardim, C., Colodette, J.L., Morales-Otero, M.D., BoladoRodríguez, S., 2015. Ozonolysis. In: Pandey, A., Negi, S., Binod, P., Larroche, C. (Eds.), Pretreatment of Biomass. Elsevier, USA, pp. 105-135.

Travaini, R., Martín-Juárez, J., Lorenzo-Hernando, A., Bolado-Rodríguez, S., 2016. Ozonolysis: An advantageous pretreatment for lignocellulosic biomass revisited. Bioresour. Technol. 199, 2-12.

Travaini, R., Otero, M.D.M., Coca, M., Da-Silva, R., Bolado, S., 2013. Sugarcane bagasse ozonolysis pretreatment: effect on enzymatic digestibility and inhibitory compound formation. Bioresour. Technol. 133, 332-339.

UNICA, 2015. Relatório final da safra de 2014/2015, região centro-sul, UNICADATA, available at <http://www.unicadata.com.br/>, last accessed September 10, 2015. São Paulo, Brasil.

Wanderley, M.C.D.A., Martín, C., Rocha, G.J.D.M., Gouveia, E.R., 2013. Increase in ethanol production from sugarcane bagasse based on combined pretreatments and fed-batch enzymatic hydrolysis. Bioresour. Technol. 128, 448-453.

Weijers, S.R., Van't Riet, K., 1992. Enzyme stability in downstream processing part 1: enzyme inactivation, stability and stabilization. Biotechnol. Adv. 10, 237249.

Zhang, F., Duan, X., Chen, S., Wu, D., Chen, J., Wu, J., 2013. The addition of $\mathrm{Co}^{2+}$ enhances the catalytic efficiency and thermostability of recombinant glucose isomerase from Thermobifida fusca. Process Biochem. 48, 1502-1508. 